\title{
The impact of accounting disclosure on emerging stock market prediction in an unstable socio-political context
}

\author{
Chaima Koolia, Raoudha Trabelsia, ${ }^{a}$ and Fethi Tlili ${ }^{b}$ \\ aSfax Business School, Sfax University, Tunisia \\ ${ }^{b}$ Tunis Higher School of Communication, Tunisia
}

\begin{abstract}
A bstract: The paper analyzes the impact of accounting disclosure on the prediction quality of stock market prices. The study also investigates whether a changing socio-political context affects the prediction quality. We focused on the Tunisian case, which has known a political turmoil in January 2011. Our sample includes 48,204 daily stock closing prices of 39 companies listed in Tunis Stock Exchange from 2009 to 2014. We used an Artificial Neural Network (ANN) with a Multi-layer Perceptron topology to predict the time series. The simulations showed that the average annual prediction error of the stock prices is the largest in the period relating to the J anuary 2011 events. Thus, the country socio-political context impacts negatively the prediction quality of the stock market prices. Furthermore, the integration of an accounting variable improves the quality of the stock prices prediction for all the study periods, except the one that corresponds to the events of January 2011. In other words, it appears that accounting disclosure does not improve prices prediction qual ity in an unstable context.
\end{abstract}

Keywords: Accounting disclosure, Socio-political context, Stock prices prediction, Pricediscovery.

J E L codes: G14, G17, M41

\footnotetext{
${ }^{1}$ Corresponding author: Department of Accounting, Sfax Business School.

Email address: raoudha.trabelsi@gmail.com
} 


\section{Introduction}

It is a well-known fact that stock prices react to accounting-based earnings disclosures (Lev, 1989). Relatively few studies analyze the impact of these accounting disclosures on the prediction of stock prices, and specifically when it comes to an unstable country context.

For decades, Tunisia, an emerging country, has been considered one of the success stories in the African continent, characterized by a Gross Domestic Product growth of $4.2 \%$ in $2008,3 \%$ in 2009 and $3.5 \%$ in 2010, according to the World Development Indicators database. Y et, on December 17, 2010 the self-immolation of a street vendor launched a revolution, and former President Zine El Abidine Ben Ali left power after a month of protests and violent confrontations.

In this changing socio-political context, it seems interesting to analyze the prediction quality of the stock market prices on the Tunis Stock Exchange, prior to and after the integration of an accounting variable. The idea here is to verify whether the integration of an accounting variable would have the same impact on the quality of the prediction in an unstable socio-political context as in a stable one.

To do this, the article aims to apply Artificial Neural Networks to predict the Tunis stock Exchange prices. Many authors question indeed conventional methods for quoted equities prediction relying on autoregressive prediction techniques and their derivatives. In fact, despite their efficiency for linear and invariant time series, these methods are not appropriate for the series of stock prices, which are known for their non-linearity and their non-stationarity. Therefore, more and more finance studies have started exploring other techniques and data analysis tools, such as artificial intelligence methods. According to Paquet (1997), contrary to the conventional approaches, these methods for intelligence simulation do not require any assumption on the variables. Accordingly, Artificial Neural Networks (ANN) which have been recognized as reliable in financial literature, are artificial intelligence techniques for processing and prediction, oriented especially for modeling complex functions.

The first objective of this work is to evaluate the prediction error of the stock market prices in different periods around the Tunisia events of January 2011, in order to verify if the socio-political events in a country impact its stock market prices prediction quality. In the second place, the research aims to compare the prediction error of the stock market prices prior to and after the integration in the prediction model of an accounting variable.

The remainder of this paper is organized as follows. Section 2 is dedicated to presenting a general overview of related literature on the impact of accounting disclosure on stock prices reaction and on the use of ANN in the prediction of 
financial time series. As for section 3, it depicts the data gathering and research sample preprocessing steps. In section 4, we expose the simulation scenario and the empirical results to be discussed in section 5. Finally, section 6 bears the paper's conduding remarks and proposed perspectives.

\section{The literature review}

The literature review will first focus on empirical studies related to the impact of accounting disclosure on stock prices. We then present the methodological aspect of the literature by exposing some of the studies that use ANN to predict financial time series.

\subsection{The impact of accounting disclosure on stock prices reaction}

There is a wide range of research showing the effect of accounting disclosure on stock prices reaction. In the following, we expose some of the existing literature first in developed markets then in emerging ones.

\subsubsection{In devel oped markets}

Ball and Brown (1968) worked on the Wall Stret stock market and showed how the net income gets reflected in stock prices. Alford et al. (1993) conducted a cross-country study to measure the impact of accounting disclosure on US firm's stock prices, and in 16 other countries, within the period 1983-1990. First, the results showed that accounting-based earnings disclosures in Australia, France, the Netherlands and the United Kingdom have a greater impact on the determination of stock prices than in the United States. Second, the study showed that earnings variables in Denmark, Germany, Italy, Singapore and Sweden display lower levels of value relevance. Alford et al. (1993) explain these different results from a country to another by the diversity in accounting standards, in financial reporting practices and in corporate governance mechanisms.

The usefulness of accounting numbers for stock prices prediction was also emphasized in the works of Ohlson (1995), related to the US Market. The author identified book values and earnings as the two fundamental accounting variables used to explain stock prices.

Having worked on earnings and book values, Collins et al. (1997, 1999) showed that the explanatory power of these two accounting variables has increased over the time.

Boozer et al. (2017) considered corporate accounting disclosure in predicting the stock prices of American companies. They found a mixed relationship on the predictive power of accounting variables on stock prices before and after the 2007- 
2009 financial crisis. The authors concluded that accounting disclosure has a predictive ability on stock prices, but only outside the crisis period.

\subsubsection{In emerging markets}

Graham and King (2000) examined the relationship between accounting disclosure and stock prices reaction among six Asian countries (Indonesia, Korea, Malaysia, the Philippines, Taiwan, and Thailand). They found significant differences across the six countries in the explanatory power of accounting variables for stock prices. The authors explained this result by diversity in accounting practices in these countries.

Using a sample of all listed firms in the Shanghai and Shenzhen Stock Exchanges from 1991 to 1998, Chen et al.(2001) provided evidence that accounting information based on Chinese GAAP impacts the stock market prices. The study also examined two competing explanations to the valuerelevance of accounting information between A-share and AB-share companies. The authors found that accounting information in A-share companies impacts more the stock prices than in AB-Share companies. Different other researches (Lin \& Chen, 2005; Liu \& Liu, 2007) focused on the Chinese case and showed the relevance of accounting disclosure in stock prices determination.

Pirie and Smith (2008) showed that two accounting variables; earnings and book value, impact considerably the stock prices in Malaysia. Based on 30 accounting variables, Rounaghi et al. (2015) tried to predict Teheran stock prices using the MARS (Multivariate Adaptive Regression Splines) model and semi-parametric splines technique As influencing variables on predicting stock prices, the authors selected 4 accounting variables (book val ue per share, predicted earnings per share, $\mathrm{P} / \mathrm{E}$ ratio and risk) using the MARS model. Using the semi-parametric splines technique, they selected 4 other accounting variables; dividends, net EPS, EPS Forecast and P/E Ratio.

Finally, Zahedi and Rounaghi (2015) worked on the Teheran stock market, and showed the positive impact of the integration of accounting variables on the stock prices prediction quality. This study is among the few that used Artificial Neural Networks (ANN), rather than the usual econometric analysis tools. Since we also used ANN in our herein analysis of the Tunisian case, we expose in the following section some of the studies that used these tools in the prediction of financial time series.

\subsection{Stock prices prediction : ANN versus traditional methods}

Although some papers undermine the use of nonparametric machine learning models for market forecasts (Preethi \& Santhi, 2012; Pyo et al., 2017), the current 
body of empirical literature includes many studies showing the importance of ANN in predicting financial time series and particularly stock prices (Tkac \& Verner, 2016).

In this context, Kimoto et al. (1990) and Slim (2004) worked on the prediction of the stock prices of respectively Tokyo and Tunis stock markets. For both studies, the prediction system achieved accurate predictions and the simulation on stocks trading has proved to be very interesting.

Donaldson and Kamstra (1996) focused on stock prices prediction with ANN in United States, Canada, Japan and British Kingdom stock markets and showed the efficiency of this tool to treat noisy data, compared to conventional tools. Similarly, Maciel and Ballini (2010) analyzed the use of ANN to predict the trend of North American, European and Brazilian stock indexes. They compared ANN and traditional methods such as GARCH (General ized Autoregressive Conditional Heteroscedasticity) and concluded the superiority of ANN. Bagherifard et al. (2012) also used ANN to predict stock prices. In the same way, the study confimed that ANN is a better performing tool than ARIMA models (AutoRegressive Integrated Moving A verage).

Furthermore, other studies focused on the ANN tool itself testing different architectures in the prediction of financial time series. As an example, Naeini et al. (2010) worked on stock indexes prediction in Teheran stock market, using several variants of ANN schemes. In this research, two types of networks were compared; MLP (MultiLayer Perceptron) and the recurrent Elman model. The results showed that while MLP provides better prediction quality of stock prices, Elman model predicts better their change direction.

Finally, Zahedi and Rounaghi (2015) worked on Teheran stock market, and showed the impact of the integration of accounting variables, as additional inputs in the ANN tool, on the stock prices prediction quality. Y et, this research focused on a sample that has been selected based on, amongst others, the stability of all the research period.

In fact, this literature review, whether it concerns developed or emerging markets, shows the lack of studies interested in the analysis of the impact of accounting disclosure on share prices, while taking into account the stability or not of the context.

That's why, within this framework, our study aims to analyze the impact of the integration of an accounting variable on the Tunis Stock Exchange prices prediction quality, within an unstable context. 


\section{Data gathering and research sample preprocessing}

The Tunis Stock Exchange was founded in 1969. Up to J anuary 2018 it includes 81 listed companies. While realizing our study, the stock exchange reports available on the Tunis Stock Exchange website go back to 2008. Thus, the adopted duration for our sample was chosen to be 2008-2014. The stock prices reports provide four daily records for each company: "Lowest", "Highest", "Opening" and "Closing", the latter was chosen in our sample selection. In this research, the sample selection was led in two steps.

Elimination of the year 2008 from the study period

A close observation of the collected stock prices dataset reveal ed that only 48 firms are continuously present over the 7 years period (2008-2014). Moreover, given that the introduction of relevant number of firms in the market took place throughout 2008 , and in order to avoid this lack of information, the 2008 data were removed from the sample, and the period was limited to 6 years (from 2009 to 2014).

Outliers elimination or rectification

In order to check data integrity, and given the large size of the sample, the evolution of the stock prices of the 48 companies over the 6 years (2009-2014) was represented graphically. These visual representations allow effective outliers detection. To do this, a linear scale representation was performed as depicted in Figure 1.

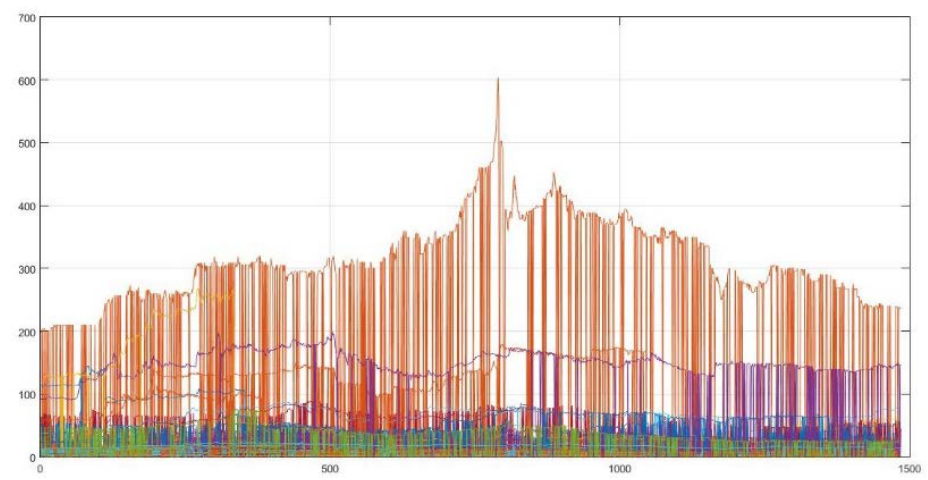

Figure 1. Evolution of the stock prices (48 companies - 2009 to 2014): L inear scale

As shown in the Figure 1, most of the 48 curves are overlapping and do not allow fine interpretation. This could be explained by the large dynamic of the stock prices over the different firms. To overcome this issue, a logarithmic scale representation is adopted as shown in Figure 2. 


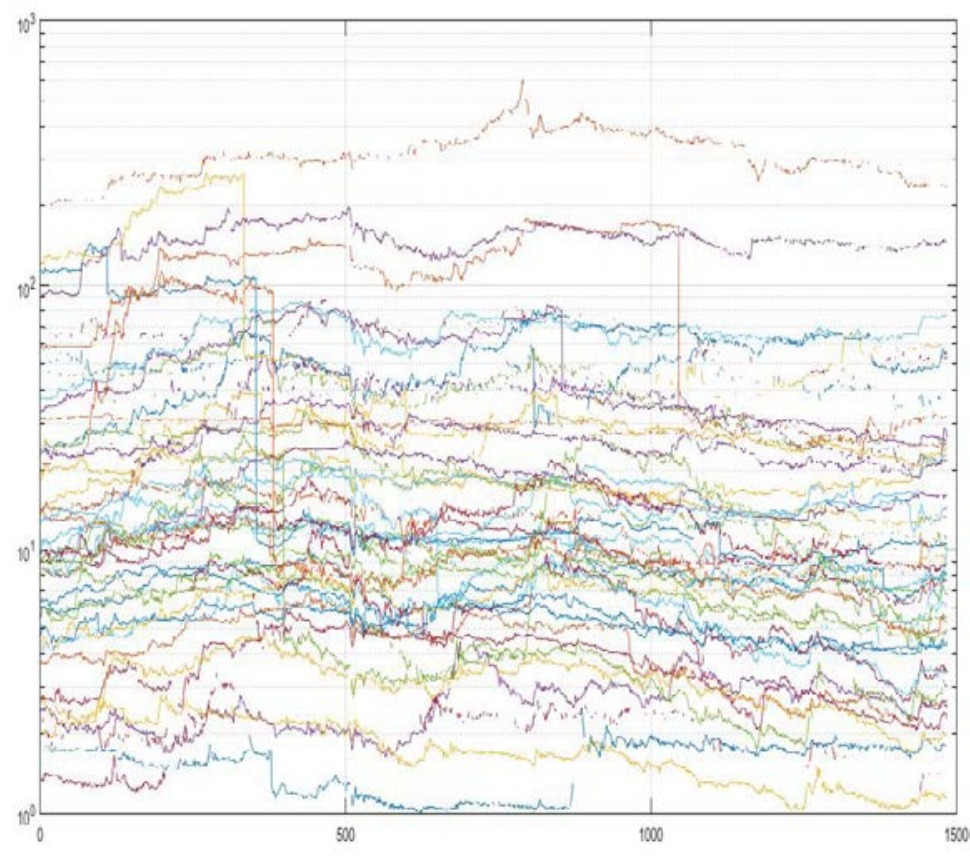

Figure 2. Evolution of the share prices

(48 companies - 2009 to 2014): L ogarithmic scale

A thorough analysis of the different curves reveals some aberrations in the collected data. Mainly, some curves look to be as dash line for given dates, which reflects quotation interruptions. For each of those particular cases, it was decided to duplicate the previous stock price value observed. Otherwise, ANN simulation tool would consider the missing values due to quotation interruptions as zero-valued, which would compromise the prediction quality.

In addition, it can be noticed a sharp drop of the stock prices for some firms, that stems from a distribution of bonus shares, whether through a stock split, or the creation of new free shares (following an incorporation of reserves in the capital). Based on historical values, the stock prices prediction would be obviously skewed by such outliers. That's why we decided to remove from our sample all the firms concerned by a split or an al location of free additional shares.

It should also be noted that, all special cases were individually analyzed through a documentary research based on the firms' annual reports and their general meetings' minutes. Table 1 summarizes all the companies that had a distribution of free shares. It specifies for each case, whether it is a split or a creation of new free shares. 
Table 1. Free shares distributions during the study period Split Allocation of free additional shares

\begin{tabular}{|c|c|c|c|c|c|c|}
\hline \multirow{2}{*}{ Firms } & \multicolumn{2}{|c|}{ Date } & \multirow{2}{*}{$\begin{array}{l}\text { Split } \\
\text { ratio }\end{array}$} & \multicolumn{2}{|c|}{ Date } & \multirow{2}{*}{ Ratio } \\
\hline & $\begin{array}{l}\text { General } \\
\text { meeting }\end{array}$ & Application & & $\begin{array}{l}\text { General } \\
\text { meeting }\end{array}$ & Application & \\
\hline BT & $\begin{array}{c}\text { May 7, } \\
2010\end{array}$ & $\begin{array}{c}\text { May 28, } \\
2010\end{array}$ & $1 / 10$ & $\begin{array}{c}\text { May 26, } \\
2009\end{array}$ & $\begin{array}{l}\text { Jun. 10, } \\
2009\end{array}$ & $1 / 3$ \\
\hline UBCI & & & & $\begin{array}{l}\text { Jun. 25, } \\
2010\end{array}$ & $\begin{array}{l}\text { Jul 16., } \\
2010\end{array}$ & $1 / 2$ \\
\hline Monoprix & $\begin{array}{l}\text { Apr. 6, } \\
2010\end{array}$ & $\begin{array}{c}\text { May 3, } \\
2010\end{array}$ & $1 / 5$ & & & \\
\hline SOPAT & & & & $\begin{array}{l}\text { Feb. 9, } \\
2010\end{array}$ & $\begin{array}{l}\text { Aug 2., } \\
2010\end{array}$ & $1 / 8$ \\
\hline SOTETEL & $\begin{array}{l}\text { Jul. 21, } \\
2011\end{array}$ & $\begin{array}{c}\text { Aug. 23, } \\
2011\end{array}$ & $1 / 2$ & & & \\
\hline SOTUVER & $\begin{array}{l}\text { J un. 14, } \\
2010\end{array}$ & Jul 8, 2010 & $1 / 10$ & & & \\
\hline $\begin{array}{l}\text { Amen } \\
\text { Bank }\end{array}$ & $\begin{array}{c}\text { Jun. 5, } \\
2012\end{array}$ & $\begin{array}{l}\text { Jun. 14, } \\
2012\end{array}$ & $1 / 2$ & & & \\
\hline ICF & & & & $\begin{array}{l}\text { Jan. } 5, \\
2012\end{array}$ & $\begin{array}{l}\text { Apr. 10, } \\
2012\end{array}$ & $1 / 4$ \\
\hline $\begin{array}{l}\text { Magasin } \\
\text { Général }\end{array}$ & $\begin{array}{l}26 \text { Feb } \\
2013\end{array}$ & 25 Mar 2013 & $1 / 5$ & & & \\
\hline
\end{tabular}

This analysis al lowed us to remove from our sample the 9 firms concerned by the distributions of free shares. This would avoid indeed that such an isolated decision taken by the Extraordinary General Meeting alters the quality of the prediction of all the share prices. Hitherto, the sample used is made up of the daily stock closing prices of 39 companies, over the period from 2009 to 2014.

\subsection{Data organization}

Knowing that the publication of financial statements of a given year shall take place by the end of March of the next year, and similarly to Olson and Mossman (2003), the data collected were organized in such a way to redefine the period of the study from April 1st to March 31st of the following year, so we can integrate the accounting variable to the prediction model. Thus, the periods from J anuary 1st to March 31st, 2009 and from April 1st to December 31st, 2014 were excluded from the sample, which redefines the study period to five subdivisions. Table 2 shows the period of the study, as well as the size of the final sample. 
The impact of Accounting disclosure on E merging Stock M arket Prediction in an unstable socio-political context

Table 2. Presentation of the final sample and the study period

\begin{tabular}{|c|c|c|c|c|c|}
\hline & $\begin{array}{c}\text { Apr.1, } 2009 \\
\text { to } \\
\text { Mar. 31, } 2010\end{array}$ & $\begin{array}{c}\text { Apr. 1, } 2010 \\
\text { to } \\
\text { Mar. 31, } 2011\end{array}$ & $\begin{array}{c}\text { Apr.1, } 2011 \\
\text { to } \\
\text { Mar. 31, } 2012\end{array}$ & $\begin{array}{c}\text { Apr.1, } 2012 \\
\text { to } \\
\text { Mar. 31, } 2013\end{array}$ & $\begin{array}{c}\text { Apr.1, } 2013 \\
\text { to } \\
\text { Mar. 31, } 2014\end{array}$ \\
\hline $\begin{array}{l}\text { Sample size by } \\
\text { year and by } \\
\text { firm }\end{array}$ & 251 & 236 & 255 & 247 & 247 \\
\hline $\begin{array}{c}\text { Total number } \\
\text { of } \\
\text { observations } \\
\text { per firm }\end{array}$ & \multicolumn{5}{|c|}{1,236 observations per firm } \\
\hline $\begin{array}{l}\text { Total number } \\
\text { of } \\
\text { observations } \\
\text { over the entire } \\
\text { period }\end{array}$ & \multicolumn{5}{|c|}{$1236 \times 39=\mathbf{4 8 , 2 0 4} 0$ bservations } \\
\hline
\end{tabular}

\section{Empirical results}

\subsection{The simulation scenario}

The prediction of the stock prices time series by means of the (ANN) toolbox in MATLAB ${ }^{\circledR}$ (R2013a edition) can receive input in various data formats; vectors in the form of rows, columns, or matrix. In this study, a matrix variable is created from the data table (stock market prices of the 39 companies, during the 5 periods of the study), and then injected in the ANN.

The ANN architecture that was adopted for our simulations has a Mult-layer Perceptron topology made up of an input layer, a hidden layer with 10 neurons and an output layer. The transfer function is a sigmoid in the hidden layer and a linear transfer function in the output layer. The training phase of the ANN was based on the Levenberg-Marquardt algorithm which is well known for its execution time efficiency. The chosen temporal prediction memory corresponds to 7 business days.

Following the injection of the time series to be analyzed in the ANN, data is then divided into three interlaced subsets, each intended for use in one of the three phases of processing: training, validation and test. The training phase ( $70 \%$ of our sample) aims to determine the settings of the ANN, in order to minimize through multiple iterations, the prediction error, i.e. the difference between predicted val ues and the actual injected data, which are known beforehand.

The validation phase ( $15 \%$ of our sample) is launched in order to confirm or, if needed, to adjust the chosen configuration of the ANN, whenever the generated prediction error exceeds a given threshold. Finally, the test phase ( $15 \%$ of our sample) operates on the third samples subset and performs data prediction by means of the ANN architecture as configured and set up by the two previous phases. 
During the training phase, it should be noted that the ANN gives different prediction results, from one iteration to another, depending on the path followed when searching for the minimum prediction error. This is commonly well known in multiple local minima problem for which the search operation may provide different results every timea new simulation is run.

One of the ways to deal with this inconvenience is to apply the Monte Carlo analysis (Metropolis \& Ulam, 1949), which is abundant in the related literature (Andor \& Bohák, 2017). In fact, we run a sufficient number of simulations (10 in our case), with the same time series as input, and to carry out the calculation of the result average. This allows to ensure a certain consistency of results.

For example, Figure 3 shows a simulation for the company "ADWY A", real ized in the first research period. It shows the evolution of the real price's curve, mentioned "Target" in the figure, as well as that of the evolution of the price predicted by the ANN, mentioned "Output". The prediction error is thus presented through the vertical lines, linking each actual share price to the predicted one. The smallest the lines are, the most efficient the ANN is. An error free prediction would be presented by a dot instead of a line.
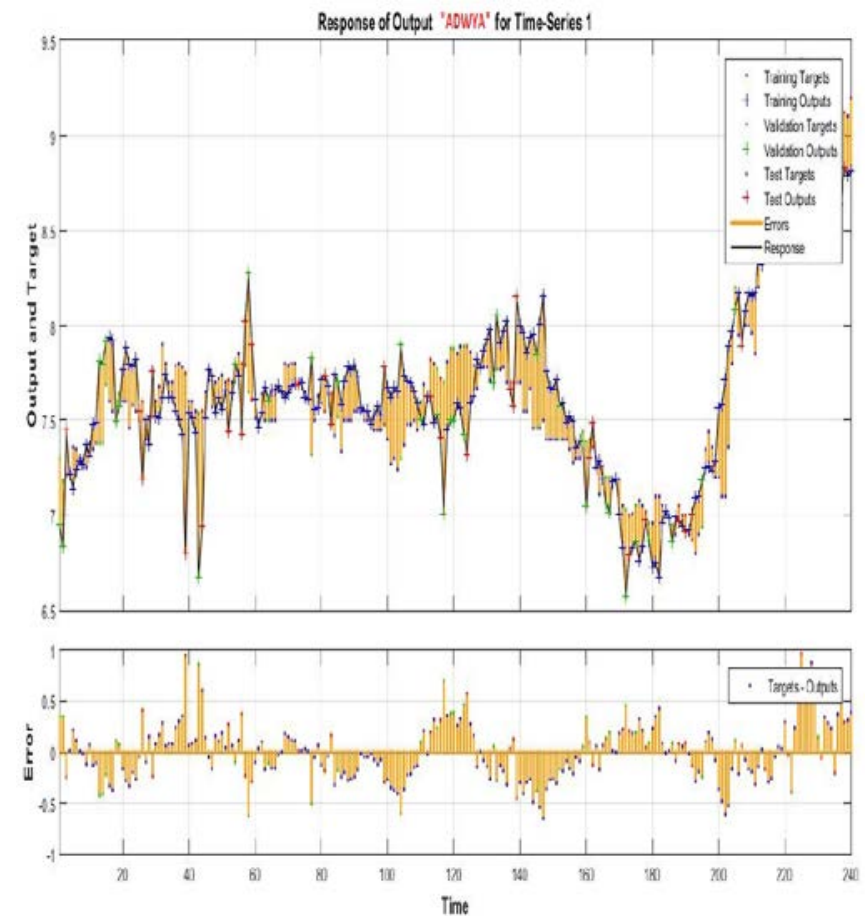

Figure 3. C urve of the market stock price of the company "ADWYA" on the first period: Real price, Predicted price and Prediction error 
4.1 Simulation of the stock market prices prediction before and after the accounting variable integration

In order to carry out a twofold analysis of the prediction quality of stock prices, simulation was run with the research sample $(48,204$ observations from 39 companies over five study periods) without and with integration of an accounting variable "Operating income".

\subsubsection{Stock market prices prediction before the accounting variable integration}

As previously explained, the ANN provides the value of the prediction error for each of the 48,204 observations from the 39 companies over the five study periods. It is worth mentioned that the only input to be injected for the simulation of the share prices prediction is their time series.

The following model has been applied in the present study to obtain stock prices prediction, namely:

$$
y(t)=f(y(t-1), \ldots y(t-d)),
$$

where $d$ stands for the temporal prediction memory, corresponding to 7 business days in our case.

Moreover, since the prediction error may have a positive or negative sign (overestimation or under-estimation of the real stock price), the average error per company and per period was evaluated considering the absolute values of the prediction errors of all observations, and it is therefore estimated in Tunisian Dinar. Also, given the very varying range of the stock prices, the average error was reported at the average value in order to provide the relative average prediction error. Table 3 gives the overall average prediction error, for the 39 companies of the research sample, and for the five research periods, which corresponds to $0.84 \%$.

Table 3. A verage prediction error before integration of the accounting variable

\begin{tabular}{|c|c|c|c|c|c|}
\hline $\begin{array}{c}\text { Apr.1, } 2009 \\
\text { to } \\
\text { Mar. } 31, \\
2010\end{array}$ & $\begin{array}{c}\text { Apr. 1, } 2010 \\
\text { to } \\
\text { Mar. } 31 \\
2011\end{array}$ & $\begin{array}{l}\text { Apr.1, } 2011 \\
\text { to } \\
\text { Mar. 31, } \\
2012\end{array}$ & $\begin{array}{l}\text { Apr.1, } 2012 \\
\text { to } \\
\text { Mar. 31, } \\
2013\end{array}$ & $\begin{array}{c}\text { Apr.1, } 2013 \\
\text { to } \\
\text { Mar. 31, } \\
2014\end{array}$ & $\begin{array}{l}\text { Average } \\
\text { prediction } \\
\text { error }\end{array}$ \\
\hline $0.56 \%$ & $1.22 \%$ & $0.95 \%$ & $0.82 \%$ & $0.63 \%$ & $0.84 \%$ \\
\hline
\end{tabular}

After calculating the stock price prediction error based solely on historical stock prices, the following subsection presents a new estimate of this prediction error after integration of the accounting variable "operating income". 
4.1.2 Stock market prices prediction with the accounting variable integration

For a prediction scheme based on two inputs (stock price history and the accounting variable "operating income"), we adopt the non-linear autoregressive model, with an external input, where the predicted stock prices are function of the past samples of time series $(y(t))$ and the variable " operating income" $(x(t))$ :

$$
y(t)=f(x(t-1), \ldots x(t-d), y(t-1), \ldots y(t-d)),
$$

where $d$ stands for the temporal prediction memory, corresponding to 7 business days in our case. Table 4 shows that the overall average prediction error, for the 39 companies and upon the five study periods, becomes $0.81 \%$ after the integration of the accounting variable "operating income".

Table 4. A verage prediction error with integration of the accounting variable

\begin{tabular}{|c|c|c|c|c|c|}
\hline $\begin{array}{c}\text { Apr.1, } 2009 \\
\text { to } \\
\text { Mar. 31, } \\
2010\end{array}$ & $\begin{array}{c}\text { Apr. 1, } 2010 \\
\text { to } \\
\text { Mar. 31, } \\
2011\end{array}$ & $\begin{array}{c}\text { Apr.1, } 2011 \\
\text { to } \\
\text { Mar. 31, } \\
2012\end{array}$ & $\begin{array}{l}\text { Apr.1, } 2012 \\
\text { to } \\
\text { Mar. 31, } \\
2013\end{array}$ & $\begin{array}{c}\text { Apr.1, } 2013 \\
\text { to } \\
\text { Mar. 31, } \\
2014\end{array}$ & $\begin{array}{l}\text { Average } \\
\text { prediction } \\
\text { error }\end{array}$ \\
\hline $0.53 \%$ & $1.86 \%$ & $0.65 \%$ & $0.43 \%$ & $0.65 \%$ & $0.81 \%$ \\
\hline
\end{tabular}

\section{Discussion}

In this study we evaluate the prediction quality of market stock prices, based on historical prices and accounting variables for listed companies, using the Artificial Neural Networks. To do so, we analyze the average prediction error of the stock prices, since its small or high value would respectively reflect a good or poor quality of prediction.

Exposing the averages of annual prediction errors for all companies of the sample, with or without accounting variables integration (the history of the variable "operating income"), Tables 3 and 4 show that, over the five periods of the study, the overall average of prediction error of all companies stock prices, does not exceed $1 \%$ (respectively $0.84 \%$ and $0.81 \%$ according to Tables 3 and 4 ).

In general, this result reflects a good quality of prediction of the stock prices of the Tunis Stock Exchange Market. In order to deepen the analysis, it is now necessary to analyze the impact on the prediction quality of two factors of different natures: the January 2011 events, and the integration in the prediction model of an accounting variable 
5.1 Impact of the socio-political context on the prediction quality of the stock market prices in Tunis Stock Exchange

With or without accounting variable integration in the prediction model, tables 3 and 4 show that the average annual prediction error of the stock prices for the 39 companies is the largest in the same period relating to the January 14th, 2011 events. In other words, as shown in Table 5, the degradation of the prediction quality for the second research period may be explained by the socio-political disturbances that the country and therefore the Tunisian stock market experienced. This result corresponds to the conclusions of Kaizoji and Miyano (2016), who, having studied the divergence rate measuring the spread between the observed prices and the intrinsic values corresponding to economic fundamentals, found that prices are overvalued during financial prosperity, and underestimated during periods of financial crisis. Furthermore, our results confirm those of Ormos and Timotity (2016), showing that in periods of great uncertainty, large deviations from fundamental prices are observed.

Table 5. Highlighting the impact of the socio-political context on the stock prices prediction quality in the T unis Stock Exchange

\begin{tabular}{cccccc}
\hline $\begin{array}{c}\text { Average } \\
\text { prediction } \\
\text { error }\end{array}$ & $\begin{array}{c}\text { Apr.1, 2009 } \\
\text { to } \\
\text { Mar. 31, 2010 }\end{array}$ & $\begin{array}{c}\text { Apr. 1, 2010 } \\
\text { to }\end{array}$ & $\begin{array}{c}\text { Apr.1, 2011 } \\
\text { to }\end{array}$ & $\begin{array}{c}\text { Apr.1, 2012 } \\
\text { to }\end{array}$ & $\begin{array}{c}\text { Apr.1, 2013 } \\
\text { to }\end{array}$ \\
\hline $\begin{array}{c}\text { Before } \\
\text { integration of } \\
\text { an accounting } \\
\text { variable(\%) }\end{array}$ & $0.56 \%$ & $1.22 \%$ & $0.95 \%$ & $0.82 \%$ & $0.63 \%$ \\
\hline $\begin{array}{c}\text { After } \\
\text { integration of } \\
\text { an accounting } \\
\text { variable(\%) }\end{array}$ & $0.53 \%$ & $1.86 \%$ & $0.65 \%$ & $0.43 \%$ & $0.65 \%$ \\
\hline
\end{tabular}

\subsection{Impact of an accounting variable integration on the prices prediction quality}

In order to evaluate the impact of the accounting variable "Operating income" on the quality of the stock prices prediction, it is necessary to compare the prediction errors obtained before and after integration of the given accounting variable, for the 39 companies and over the fivestudy periods.

Thus, a positive difference reflects an improvement of the prediction quality, due to the consideration of the "operating income" in the stock prices prediction. Otherwise, a negative difference shows that the integration of the accounting 
variable in the simulation model does not improve the stock prices prediction quality. Table 6 summarizes the obtained results.

Table 6. Highlighting the impact of an accounting variable integration on the quality of prices prediction

\begin{tabular}{cccccc}
\hline $\begin{array}{c}\text { Average } \\
\text { prediction error }\end{array}$ & $\begin{array}{c}\text { Apr.1, 2009 } \\
\text { to }\end{array}$ & $\begin{array}{c}\text { Apr. 1, 2010 } \\
\text { to }\end{array}$ & $\begin{array}{c}\text { Apr.1, 2011 } \\
\text { to }\end{array}$ & $\begin{array}{c}\text { Apr.1, 2012 } \\
\text { to }\end{array}$ & $\begin{array}{c}\text { Apr.1, 2013 } \\
\text { to }\end{array}$ \\
\hline $\begin{array}{c}\text { Before } \\
\text { integration of } \\
\text { an accounting } \\
\text { variable(\%) }\end{array}$ & $0.56 \%$ & $1.22 \%$ & $0.95 \%$ & $0.82 \%$ & $0.63 \%$ \\
\hline $\begin{array}{c}\text { After } \\
\text { integration of } \\
\text { an accounting } \\
\text { variable(\%) }\end{array}$ & $0.53 \%$ & $1.86 \%$ & $0.65 \%$ & $0.43 \%$ & $0.65 \%$ \\
\hline $\begin{array}{c}\text { Variation of } \\
\text { Annual } \\
\text { prediction } \\
\text { quality }\end{array}$ & $0.03 \%$ & $-0.86 \%$ & $0.65 \%$ & $0.43 \%$ & $0.56 \%$ \\
$\begin{array}{c}\text { Improvement/ } \\
\text { Degradation }\end{array}$ & & & & & \\
\hline
\end{tabular}

Table 6 shows that the integration of the "Operating income" variable in the Artificial Neural Network simulation improves the quality of the prediction of market stock prices in four research periods among the five considered ones. Our results are consistent with those of Zahedi and Rounaghi (2015), based on Teheran stock market, and showing the positive impact of the integration of accounting variables, as additional inputs in the ANN tool, on the stock prices prediction quality. Indeed, taking into account the said accounting variable, the only period in which an increase in the prediction error and therefore a degradation of the quality of prediction is observed, is that during which the events of January 14th, 2011 took place in Tunisia. The same results were obtai ned by Boozer et al. (2017), who worked on American companies and found a mixed relationship on the predictive power of accounting variables on stock prices before and after the 2007-2009 financial crisis. The authors concluded that accounting disclosure has a predictive ability on stock prices, but only outside the crisis period.

These results can be interpreted by the fact that, whether in an emerging country (Tunisia) or developed one (US), in times of disruption, market efficiency, as defined by Fama (1965), is considerably altered. Indeed, according to this author, an "efficient" market is one "where there are large numbers of rational, profitmaximizers actively competing, with each trying to predict future market values of individual securities, and where important current information is almost freely available to all participants". Obviously, information risk increases in an unstable 
period in such a way that accounting disclosure becomes less reliable as a determinant of the market prices discovery. According to the same logic, it appears that accounting discl osure does not improve prices prediction qual ity in an unstable context.

\section{Conclusions}

This paper has been designed to predict, by Artificial Neural Network, the stock market prices on the Tunis Stock Exchange, given the socio-political country context, and by integrating an accounting variable in the prediction model. Considering a final sample of 48,204 daily stock closing prices of 39 companies, over the period from 2009 to 2014, some evidence consistent with the stock market prices prediction quality has been discovered to persist. Our empirical results demonstrate that the average annual prediction error of the stock prices for the 39 companies is the largest in the period relating to the J anuary 14th, 2011 events. In other words, the Tunisian socio-political context impacts negatively the prediction quality of thestock market prices in Tunis Stock Exchange.

We al so find that the integration of an accounting variable in the Artificial Neural Network simulation improves the quality of the prediction of market stock prices, with the exception of the period in which the events of January 14th, 2011 took place in Tunisia. In other words, it appears that accounting disclosure does not improve prices prediction quality in an unstable context.

As a matter of fact, the contribution provided by the present work is threefold: theoretical, methodological and practical. Regarding the theoretical contribution, it involves validating the accounting variable disclosure positive impact and the unstable socio-political context negative impact on stock prices prediction quality. Methodologically, our research study has helped us assess the superiority of the non-linear autoregressive model with an external input (the accounting variable), compared to non-linear model based only on the past samples of time series, in predicting stock prices with ANN. This would constitute a test of the hypothesis of weak-form market efficiency, not through the conventional random walk test, but through an artificial neural network model. Moreover, our contributions can be clearly noticed at the practical level. Indeed, they serve to draw the investors' attention to the country contextual changes risks on the stock prices stability, even with accounting variable disclosure.

We highlight, still, that some limits are worth underlining as potential research perspectives. The first perspective concerns the possibility to integrate additional accounting variables in the prediction model. As for the second perspective, it has to do with the research period, which can be expanded. Finally, a further possible extension of this study would be to explore the institutional investors' impact on stock prices prediction. 


\section{R eferences}

Alford, A., Jones, J., Leftwich, R. \& Zmijewski, M. (1993) "The relative informativeness of accounting disclosures in different countries", J ournal of Accounting Research, Vol. 31: 183-223

Andor, G. \& Bohák, A. (2017) "I dentifying events in financial time series - A new approach with bipower variation", Finance Research Letters, Vol. 22: 1-280

Bagherifard, K., Nilashi, M., Ibrahim, O., Janahmadi, N. \& Ebrahimi, L. (2012) "Comparative study of Artificial Neural Network and ARIMA models in predicting exchange rate", Research J ournal of Applied Sciences, Engineering and Technology, Vol. 4, No. 21: 4397-4403

Ball, R. \& Brown, P. (1968) "An empirical evaluation of accounting income numbers", J ournal of Accounting Research, Vol. 6, No. 2: 159-178

Boozer, B.B., Rainwater, L.H. \& Lowe, S.K. (2017) "Using financial statement variables to predict stock prices: Lessons from the 2007-2009 financial crisis", J ournal of Finance and Accountancy, Vol. 21.

Chen, C. J., Chen, S. \& Su, X. (2001) "Is accounting information valuerelevant in the emerging Chinese stock market?", J ournal of International Accounting, Auditing and Taxation, Vol. 10, No. 1: 1-22

Collins, D.W., Maydew, E.L. \& Weiss, I. (1997) "Changes in the valuerelevance of earnings and book values over the past forty years", J ournal of Accounting and Economics, Vol. 24: 39-67

Collins, D.W., Pincus, M., \& Xie, H. (1999) "Equity valuation and negative earnings: The role of book value of equity", Accounting Review, Vol. 79: 2961.

Donaldson, R. G. \& Kamstra, M. (1996) "Forecast combining with neural networks", J ournal of Forecasting, Vol. 15, No. 1: 49-61.

Fama, E. F. (1965) "The behavior of stock market prices", J ournal of Business, Vol. 38:31-105.

Graham R. C. \& King R. D. (2000) "Accounting practices and the market valuation of accounting numbers: evidence from Indonesia, Korea, Malaysia, the Philippines, Taiwan, and Thailand", The International Journal of Accounting, Vol. 35, No. 4: 445-470

Kaizoji, T. \& Miyano, M. (2016) "Why does the power law for stock price hold?", Chaos, Solitons \& Fractals, Vol. 88: 19-23

Kimoto, T., Asakawa, K., Y oda, M. \& Takeoka, M. (1990) "Stock market prediction system with modular neural network", in proceedings of the International J oint Conference on Neural Network, San Diego, 1990, CA: 1-6.

Lev, B. (1989) "On the usefulness of earnings and earnings research: lessons and directions from two decades of empirical research", J ournal of Accounting Research, Vol. 27: 153-192.

Lin, Z. J. \& Chen, F. (2005) "Value relevance of international accounting standards harmonization: evidence from A- and B-share markets in China", J ournal of International Accounting, Auditing and Taxation, Vol. 14: 79-103. 
Liu, J. \& Liu, C. (2007) "Value relevance of accounting information in different stock market segments: The case of Chinese A-, B, and H-shares, J ournal of International Accounting Research, Vol. 6: 55-81

Maciel, L.S. \& Ballini, R. (2010) “Neural networks applied to stock market forecasting: An empirical analysis", J ournal of the Brazilian Neural Network Society, Vol. 8, Issue 1: 3-22

Metropolis, N. \& Ulam, S. (1949) "The Monte Carlo method", J ournal of the American Statistical Association, Vol. 44: 335-341.

Mossman, C. \& Olson, D. (2003) "Neural network forecasts of Canadian stock returns using accounting ratios", International J ournal of Forecasting, Vol. 19, No. 3: 453-465

Naeini, M.P., Taremian, H. \& Hashemi, H.B. (2010) "Stock market value prediction using neural networks", in Computer Information Systems and Industrial Management Applications (CISIM) 2010 proceedings of the international conference in Krakow, Poland, 2010: 132-136

Ohlson, J. A. (1995) "Earnings, book values and dividends in security val uation", Contemporary Accounting Research, Vol. 11: 661-687

Ormos, M. \& Timotity, D. (2016) "Market microstructure during financial crisis: dynamics of informed and heuristic-driven trading", Finance Research Letters, Vol. 19: 60-66

Paquet, P. (1997) “L'utilisation des Réseaux de Neurones Artificiels en finance”, working paper No. 1997-1, Laboratoire Orléanais de Gestion, Orleans University, Orleans

Preethi, G. \& Santhi, B. (2012) "Stock market forecasting techniques: a survey", J ournal of Theoretical and Applied Information Technology, Vol. 46, No. 1

Pyo, S., Lee, J., Cha, M. \& Jang, H. (2017) "Predictability of machine learning techniques to forecast the trends of market index prices: Hypothesis testing for the Korean stock markets", PLOS ONE, Vol. 12, No. 11

Rounaghi, M.M., Abbaszadeh, M.R. \& Arashi, M. (2015) "Stock price forecasting for companies listed on Tehran Stock Exchange using multivariate Adaptive Regression Splines model and semi-parametric splines technique", Physica A: Statistical Mechanics and its Applications, Vol. 438: 625-633

Slim C. (2004) "Forecasting the volatility of stock index returns: a stochastic neural network approach", in Computational Science and Its Applications (ICCSA) 2004 proceedings of the international conference in Assisi, Italy, 2004, Springer: 14-17

Tkac, M. \& Verner, R. (2016) "Artificial neural networks in business: Two decades of research", Applied Soft Computing, Vol. 38: 788-804

Zahedi, J. \& Rounaghi, M. M. (2015) "Application of artificial neural network models and principal component analysis method in predicting stock prices on Tehran Stock Exchange", Physica A: Statistical Mechanics and Its Applications, Vol. 438: 178-187 